\title{
FGF3 wt Allele
}

National Cancer Institute

\section{Source}

National Cancer Institute. FGF3 wt Allele. NCI Thesaurus. Code C51495.

Human FGF3 wild-type allele is located within 11 q13 and is approximately $9 \mathrm{~kb}$ in length.

This allele, which encodes fibroblast growth factor 3 protein, plays a role in cellular growth and signal transduction. Frequent amplification of this allele has been found in human tumors, which may be important for neoplastic transformation and tumor progression. 